\title{
Selective inhibition of histone deacetylase 8 improves vascular hypertrophy, relaxation, and inflammation in angiotensin II hypertensive mice
}

Hae Jin Kee ${ }^{1,2^{*}}$ (D) Yuhee Ryu ${ }^{1,2}$, Young Mi Seok ${ }^{3}$, Sin Young Choi ${ }^{1,2,4}$, Simei Sun ${ }^{1,2,4}$, Gwi Ran Kim ${ }^{1,2}$ and Myung Ho Jeong ${ }^{1,2^{*}}$

\begin{abstract}
Background: The dysregulation of histone deacetylase (HDAC) protein expression or its enzyme activity is implicated in a variety of diseases. Cardiac HDAC6 and HDAC8 enzyme activity induced by deoxycorticosterone acetate (DOCA) hypertension was attenuated by sodium valproate, a pan-HDAC inhibitor. However, the HDAC6selective inhibitor, tubastatin A, did not attenuate angiotensin Il-induced hypertension. The purpose of this study was to investigate whether PCI34051, an HDAC8-selective inhibitor, can modulate angiotensin II-induced hypertension and its regulatory mechanism.
\end{abstract}

Methods: An angiotensin II-regulated mouse model was used in this study. Animals received vehicle or PCI34051 (3 mg.kg $-{ }^{1}$.day $\left.-{ }^{1}\right)$ via intraperitoneal injection. Systolic blood pressure was measured by the tail-cuff method. Blood vessel thickness was measured following hematoxylin and eosin staining, VCAM-1 immunohistochemistry was performed in the aortas, and mRNA expression of renin-angiotensin system components, inflammation markers, and NADPH oxidase (Nox) was determined by RT-PCR. The effect of PCI34051 on vasorelaxation was studied in rat aortic rings, and its effect on nitric oxide (NO) production was determined using DAF-FM DA, a fluorescent dye, in human umbilical vascular endothelial cells (HUVECs).

Results: PCl34051 administration reduced systolic blood pressure via downregulation of angiotensin II receptor type 1 (AT1) mRNA expression. PCI34051 treatment attenuated vascular hypertrophy by decreasing E2F3 and GATA6 mRNA expression. Vascular relaxation after PCl34051 treatment was more dependent on vascular endothelial cells and it was blocked by an NO synthase (NOS) inhibitor. In addition, NO production increased in HUVECs after PCI34051 treatment; this was decreased by the NOS inhibitor. The expression of inflammatory molecules and adhesion molecules VCAM-1 and ICAM-1 decreased in the aortas of angiotensin II-infused mice after PCI34051 administration. However, PCI34051 did not affect Nox or its regulatory subunits.

Conclusions: PCI34051 lowered high blood pressure through modulation of arterial remodeling, vasoconstriction, and inflammation in an angiotensin Il-induced hypertension model. We suggest that HDAC8 could be a potential therapeutic target for hypertension.

Keywords: PCl34051, Hypertension, Arterial remodeling, Vascular relaxation, Inflammation

\footnotetext{
* Correspondence: sshjkee@empas.com; myungho@chollian.net

'Heart Research Center of Chonnam National, Jebong-ro, Dong-gu, Gwangju

61469, Republic of Korea

Full list of author information is available at the end of the article
}

(c) The Author(s). 2019 Open Access This article is distributed under the terms of the Creative Commons Attribution 4.0 International License (http://creativecommons.org/licenses/by/4.0/), which permits unrestricted use, distribution, and reproduction in any medium, provided you give appropriate credit to the original author(s) and the source, provide a link to the Creative Commons license, and indicate if changes were made. The Creative Commons Public Domain Dedication waiver (http://creativecommons.org/publicdomain/zero/1.0/) applies to the data made available in this article, unless otherwise stated. 


\section{Background}

Continuously high blood pressure causes multiple complications, including stroke, hypertensive retinopathy, myocardial infarction, heart failure, and chronic renal failure [1, 2]. High blood pressure is known as a silent killer because there are no symptoms and therefore it can go untreated for long periods of time. It is known that the control rate is no more than $40 \%$ even when hypertensive patients receive two or more antihypertensive drugs [3]. Inflammatory responses are involved in the pathophysiology of hypertension [4]. Recent evidence has revealed inflammation in the vessel structure of animal models of hypertension [5].

Angiotensin II is a vasoconstrictor, causing vascular inflammation in arteries as well as in the kidneys and heart $[6,7]$. It increases the expression of adhesion molecules, cytokines, and chemokines in endothelial cells and vascular smooth muscle cells [8]. Vascular cell adhesion molecule-1 (VCAM-1), intercellular adhesion molecule-1 (ICAM-1), and platelet endothelial cell adhesion molecule (PECAM) may be implicated in hypertension [9]. However, soluble E-selectin has been significantly associated with blood pressure [10]. In contrast, soluble VCAM-1 (sVCAM-1) is elevated in older men with uncomplicated essential hypertension [11]. Recent evidence showed that expression of VCAM-1 is positively correlated with coronary lesion severity in atherosclerotic patients [12]. In addition, VCAM-1 was reported to be a biochemical marker of left ventricular mass in patients with uncomplicated hypertension [13].

The renin-angiotensin system (RAS) is the most important and well-known hormone system for controlling hypertension. Angiotensin-converting enzyme (ACE) converts angiotensin I to angiotensin II. Angiotensin II acts through angiotensin II receptor type 1 (AT1), which leads to vasoconstriction and inflammation [14]. An angiotensin II receptor blocker (ARB) reduces high blood pressure and inflammation by interfering with AT1 binding. Currently, ACE inhibitors and ARBs are widely used as hypertension treatments in clinical trials.

Hypertension is caused by increased resistance of blood vessels. Blood vessels are mainly composed of smooth muscle cells and endothelial cells. Endothelial cells secret substances that relax blood vessels, such as nitric oxide (NO), and substances that contract blood vessels, for example, endothelin-1. Vascular smooth muscle cells control blood pressure mainly through vascular contraction and relaxation. Contraction of smooth muscle cells is mainly due to changes in calcium concentration. Phosphorylation of myosin light chains is effected by myosin light chain kinase (MLCK), and arterial smooth muscle contracts through $\mathrm{Ca}^{2+} / \mathrm{MLCK}$ pathways $[15,16]$.
Histone deacetylases (HDACs) and their inhibitors have been extensively studied in cancer and they are now attracting attention in cardiovascular disease research [17]. HDACs are classified into class I (HDAC1, 2, 3, and 8), class IIa (HDAC4, 5, 7, and 9), class IIb (HDAC6 and 10), class III (sirtuins1-7), and class IV (HDAC11), based on their sequence. HDAC inhibitors have been shown to be effective in cardiac hypertrophy, fibrosis, heart failure, and restenosis [18-20]. Furthermore, the HDAC inhibitor, valproic acid, attenuated blood pressure in spontaneously hypertensive rats and deoxycorticosterone acetate (DOCA)- induced hypertensive rats [21, 22]. However, there was no use of isoform-specific HDAC inhibitors in these reports. We have published a study showing that HDAC6 and 8 enzyme activities are increased in the hearts of DOCA hypertensive rats [23]. We demonstrated that the HDAC6-selective inhibitor, tubastatin A, did not affect high blood pressure in an angiotensin II-induced hypertensive mouse model. Therefore, we hypothesized that HDAC8 may have a role in hypertension. To provide evidence supporting this hypothesis, we decided to investigate the effect of the HDAC8-selective inhibitor, PCI34051, on blood pressure in angiotensin II-induced hypertensive mice.

\section{Methods}

\section{Animal model and blood pressure measurement}

Angiotensin II (Ang II) was obtained from EMD Millipore (Billerica, MA, USA). PCI34051 was purchased from Selleckchem (Houston, TX, USA). CD-1 male mice (aged 8 weeks) were purchased from Orient Bio Company (Gyeonggi-do, South Korea). All animal experiments were approved by the Animal Experiment Committee of the Chonnam National University Medical School (CNU IACUC-H-2017-70) and carried out in accordance with the Guide for the Care and Use of Laboratory Animals (US National Institutes of Health Publication, 8th edition, 2011). Mice were anesthetized with ketamine $(120 \mathrm{mg} / \mathrm{kg})$ and xylazine $(6.21 \mathrm{mg} / \mathrm{kg})$, and a $1 \mathrm{~cm}$ incision was made in the back. Ang II (1.3 mg. $\mathrm{kg}^{-1} \cdot \mathrm{day}^{-1}, \mathrm{n}=8$ per group) was infused via an $\mathrm{ALZET}^{\oplus}$ osmotic pump as described previously. Ang II was dissolved in $0.9 \% \mathrm{NaCl}$ solution. The sham control mice received dimethyl sulfoxide vehicle (DMSO; $\mathrm{n}=8)$. PCI34051 (3 $\left.\mathrm{mg} \cdot \mathrm{kg}^{-1} \cdot \mathrm{day}^{-1}\right)$ was administered to the mice ( $n=8$ per group) by intraperitoneal injection from the eighth to the fourteenth day after Ang II infusion began. Blood pressure was measured three times a week in conscious animals by the tail-cuff method. Systolic blood pressure was determined on the fourteenth day after Ang II infusion began. 


\section{Hematoxylin and eosin (H\&E) staining}

Aorta tissues were fixed in $4 \%$ paraformaldehyde at $25^{\circ}$ $\mathrm{C}$, embedded in paraffin, and cut into $3 \mu \mathrm{m}$ thick sections. The tissue slides were deparaffinized three times with xylene and hydrated using serially diluted ethanol. After dipping in tap water for $2 \mathrm{~min}$, the slides were stained with Gill's hematoxylin V for 5 min, washed in tap water for $5 \mathrm{~min}$, and in 95\% ethanol for $2 \mathrm{~min}$. The slides were stained using Eosin Y for 1 min, dehydrated with ethanol and xylene, and mounted using Canada balsam. The aortic wall thickness was measured using NIS Elements Software (Nikon, Japan).

\section{Immunohistochemistry}

Aorta tissues were fixed in $4 \%$ paraformaldehyde at $25^{\circ}$ $\mathrm{C}$, embedded in paraffin, and cut into $3-\mu \mathrm{m}$-thick sections. After deparaffinization in xylene, the tissues were subjected to antigen retrieval using $10 \mathrm{mM}$ citrate-phosphate buffer $\left(\mathrm{pH}\right.$ 6.0) and incubated in $3 \% \mathrm{H}_{2} \mathrm{O}_{2}$ for 10 min. To remove non-specific binding, an Avidin/Biotin blocking kit (Abcam, USA) was used, and the sections were then blocked with $1 \%$ bovine serum albumin in PBS for 10 min. Sections were incubated overnight with mouse monoclonal VCAM-1 antibody (1:50, Santa Cruz) at $4^{\circ} \mathrm{C}$ and washed in PBS before being incubated with prediluted biotinylated pan- specific universal secondary antibody (R.T.U. VECTASTAIN kit) for $30 \mathrm{~min}$ at $25^{\circ} \mathrm{C}$. Tissues were washed with PBS, incubated in streptavidin/peroxidase complex for $5 \mathrm{~min}$, and again washed with PBS. The tissues were incubated in DAB (peroxidase substrate kit, SK-4100) for $7 \mathrm{~min}$. Sections were stained with hematoxylin for $30 \mathrm{~s}$ and washed and mounted. Images were captured using a fluorescent microscope (Eclipse 80i, Nikon, Japan).

\section{Isometric tension measurement}

The vasoconstriction-relaxation study was performed as described previously. Male Sprague- Dawley rats were purchased from Orient Bio (Gyeonggi-do, South Korea). Briefly, thoracic aortas were excised and immersed in ice-cold modified Krebs solution. The aortas were cleaned of all connective tissue, soaked in Krebs-bicarbonate solution, and cut into four ring segments (3.5 $\mathrm{mm}$ in length). Each aortic ring was suspended in a water-jacketed organ bath $(6 \mathrm{ml})$ maintained at $37^{\circ} \mathrm{C}$ and aerated with a mixture of $95 \% \mathrm{O}_{2}$ and $5 \% \mathrm{CO}_{2}$. Each ring was connected to an isometric force transducer (Danish Myo Technology, Skejbyparken, Aarhus N, Denmark). Rings were stretched to an optimal resting tension of $2.0 \times g$ or $1.0 \times g$, which was maintained throughout the experiment. Each ring was equilibrated in the organ bath solution for 90 min before measuring the contractile response after the addition of $50 \mathrm{mM} \mathrm{KCl}$. To determine the effect of PCI34051 on the maintenance of vascular tension in rat endothelium-intact or endothelium-denuded aortic rings, vascular contractions were induced using the thromboxane A2 agonist, U46619 (30 $\mathrm{nM}, 20 \mathrm{~min}$ ). When each contraction reached a plateau, increasing concentrations of PCI34051 $(0.003-3 \mu \mathrm{M})$ were added cumulatively to elicit vascular relaxation.

In the second experiment, we investigated the inhibition of the relaxation response by treating endothelium-intact aortic rings with $\mathrm{N}^{\mathrm{G}}$-nitro-L-arginine methyl ester (L-NAME, 10 and $100 \mu \mathrm{M}$ ) for $30 \mathrm{~min}$. After U46619 treatment, increasing concentrations of PCI34051 (0.003 $1 \mu \mathrm{M})$ were added cumulatively to the aortic rings.

\section{Cell culture}

Human umbilical vein endothelial cells (HUVECs) were obtained from Gibco (Waltham, MA, USA). HUVECs were grown in endothelial cell basal medium (EBM) with an EGM-2 bullet kit (Lonza, Walkersville, MD) and maintained at $37^{\circ} \mathrm{C}$ under $5 \% \mathrm{CO}_{2}$. The cells were subcultured when they reached approximately $90 \%$ confluency. Cells were used from passages five to seven. The vascular smooth muscle cells (VSMCs) were isolated from rat aortas as described previously [24]. VSMCs were maintained in low glucose with Dulbecco's modified Eagle medium (DMEM) containing 10\% fetal bovine serum. VSMCs were used from passages five to nine.

\section{Western blot analysis}

VSMCs were lysed with RIPA buffer (150 mM NaCl; $1 \%$ Triton X-100; 1\% sodium deoxycholate; $50 \mathrm{mM}$ Tris-HCl, $\mathrm{pH}$ 7.5; 2 mM EDTA; $1 \mathrm{mM}$ PMSF; $1 \mathrm{mM}$ DTT; $1 \mathrm{mM} \mathrm{Na}$ VO4; and $5 \mathrm{mM} \mathrm{NaF)} \mathrm{containing} \mathrm{a}$ protease inhibitor cocktail. The proteins were subjected to $10 \%$ SDS-PAGE and transferred on to polyvinylidene difluoride (PVDF) membranes. The membranes were blocked with 5\% skim milk in Tris-buffered saline with Tween 20 (TBST) buffer $(20 \mathrm{mM}$ Tris, $200 \mathrm{mM} \mathrm{NaCl}$, and $0.04 \%$ Tween $\left.^{\circ} 20\right)$ for $1 \mathrm{~h}$ at $25^{\circ} \mathrm{C}$. The membranes were incubated overnight at $4{ }^{\circ} \mathrm{C}$ with HDAC8 antibody (Santa Cruz) and then incubated with anti-mouse horseradish-peroxidase-conjugated secondary antibody (1:5000) for $1 \mathrm{~h}$ at $25^{\circ} \mathrm{C}$. The protein bands were visualized using Immobilon Western detection reagents (EMD Millipore). Bio-ID software was used to quantify the protein expression (Vilber Lourmat, Eberhardzell, Germany).

\section{DAF-FM imaging of NO}

The production of $\mathrm{NO}$ was estimated using a NO-sensitive fluorescence probe, 4-amino-5- methylamino-2', $7^{\prime}$-difluorofluorescein diacetate (DAF-FM DA, Cayman). HUVECs were seeded on coverslips in 12-well plates. Cells were serum-starved with EBM for $16 \mathrm{~h}$, and were treated with PCI34051 $(1 \mu \mathrm{M})$ or L-NAME $(250 \mu \mathrm{M})$ for $24 \mathrm{~h}$ and then incubated with DAF-FM DA $(2.5 \mu \mathrm{M})$ at $37^{\circ} \mathrm{C}$ for $30 \mathrm{~min}$. 
Cells were fixed using 70\% ethanol for $45 \mathrm{~min}$, washed three times with PBS, and mounted using Prolong Gold antifade reagent with DAPI (Invitrogen, USA).

\section{Reverse transcription polymerase chain reaction}

Total RNA was isolated with TriZol reagent (Invitrogen Life Technologies, Waltham, MA, USA), and $1 \mu \mathrm{g}$ of RNA was used for the reverse transcription reaction using TOPscript RT DryMIX (Enzynomics, Daejeon, South Korea). mRNA expression was determined using the SYBR Green PCR kit (Enzynomics, Daejeon, South Korea). All data were normalized to GAPDH expression using the $2^{-\Delta \Delta c t}$ method. The PCR primers used in this study are shown in Table 1.

\section{Fluorogenic HDAC enzyme activities}

To evaluate the HDAC enzyme inhibitory activity of PCI34051, we determined the activities of HDAC1, HDAC2, HDAC3, and HDAC8 using enzyme assay kits (BPS Bioscience, San Diego, CA, USA) according to the manufacturer's protocols. HDAC activities were measured using a fluorometer (Spectra Max GEMINI XPS, Molecular Devices, Sunnyvale, CA, USA) at excitation and emission wavelengths of $350 \mathrm{~nm}$ and $460 \mathrm{~nm}$, respectively. To test the inhibitory activity of PCI34051, concentrations of $0.001,0.003,0.01,0.03,0.1,0.3,1$, and $3 \mu \mathrm{M}$ were used. For the half-maximal inhibitory concentration $\left(\mathrm{IC}_{50}\right)$ calculations, every data point was normalized to the vehicle (100\% activity). The normalized data were fitted using a Hill nonlinear curve (OriginPro 9.0). The "Find $X$ from $Y$ " function in OriginPro 9.0 was used to determine the $\mathrm{IC}_{50}$ values ( $50 \%$ activity).

\section{Statistical analyses}

Statistical analysis was performed using one-way analysis of variance (ANOVA) followed by the Bonferroni post-hoc test to compare the treatment groups (GraphPad Prism, version 5.0; GraphPad Software, La Jolla, CA, USA). Data are presented as the mean \pm SEM. A value of $P<0.05$ was considered statistically significant.

\section{Results}

HDAC8-selective inhibitor $\mathrm{PCI} 34051$ reduces blood pressure through down-regulation of AT1 in Ang IIinduced hypertensive mice

PCI34051 is known to selectively inhibit HDAC8 $[25,26]$. We confirmed that PCI34051 selectively inhibits HDAC8, with an IC50 of $0.02 \mu \mathrm{M}$. The IC50 for HDAC1 was 1.22 $\mu \mathrm{M}$, while those for HDAC2 and HDAC3 were higher than $10 \mu \mathrm{M}$ (Table 2). To determine whether PCI34051 affects HDAC8 expression in VSMCs, we performed western blot analysis. PCI34051 treatment was found to significantly reduce HDAC8 protein expression (Fig. 1a
Table 1 Primers for the reverse transcription polymerase chain reaction (RT-PCR)

\begin{tabular}{|c|c|}
\hline $\begin{array}{l}\text { Gene } \\
\text { (mouse or rat) }\end{array}$ & Primer sequence ( $5^{\prime}$ to $\left.3^{\prime}\right)$ \\
\hline AT1 (mouse) & $\begin{array}{l}\text { F: GGAAACAGCTTGGTGGTGAT } \\
\text { R: GGCCGAAGCGATCTTACATA }\end{array}$ \\
\hline ACE1 (mouse) & $\begin{array}{l}\text { F: CAGTGTCTACCCCCAAGCAT } \\
\text { R: TTCCATCAAAGACCCTCCAG }\end{array}$ \\
\hline Nox1 (mouse) & $\begin{array}{l}\text { F: AGCCATTGGATCACAACCTC } \\
\text { R: TGGATGGGATTTAGCCAAGA }\end{array}$ \\
\hline Nox2 (mouse) & $\begin{array}{l}\text { F: TGTCATTCTGGTGTGGTTGG } \\
\text { R: GAACCCCTGAGGAAGGAGAG }\end{array}$ \\
\hline Nox4 (mouse) & $\begin{array}{l}\text { F: CTGGAAGAACCCAAGTTCCA } \\
\text { R: ACTGGCCAGGTCTTGCTITA }\end{array}$ \\
\hline p22phox (mouse) & $\begin{array}{l}\text { F: AAAGAGGAAAAAGGGCTCCA } \\
\text { R: CTGCCAGCAGGTAGATCACA }\end{array}$ \\
\hline p47phox (mouse) & $\begin{array}{l}\text { F: ATCCCAACTACGCAGGTGAA } \\
\text { R: TATCTCCTCCCCAGCCTTCT }\end{array}$ \\
\hline GATA6 (mouse) & $\begin{array}{l}\text { F: GAGGACCTGTCGGAGAGCCG } \\
\text { R: GCAAGTGGTCGAGGCACCCC }\end{array}$ \\
\hline E2F3 (mouse) & $\begin{array}{l}\text { F: ATCCAAAGCTGTACCCTGGA } \\
\text { R: TGGGTACTTGCCAAATGGAT }\end{array}$ \\
\hline iNOS (mouse) & $\begin{array}{l}\text { F: CTCACTGGGACAGCACAGAA } \\
\text { R: TGGTCAAACTCTTGGGGTTC }\end{array}$ \\
\hline TNF-a (mouse) & $\begin{array}{l}\text { F: AGCCCCCAGTCTGTATCCTT } \\
\text { R: CTCCCTITGCAGAACTCAGG }\end{array}$ \\
\hline IL-1 (mouse) & $\begin{array}{l}\text { F: GCCCATCCTCTGTGACTCAT } \\
\text { R: AGGCCACAGGTATITTGTCG }\end{array}$ \\
\hline MCP-1 (mouse) & $\begin{array}{l}\text { F: AGGTCCCTGTCATGCTTCTG } \\
\text { R: TCTGGACCCATTCCTTCTTG }\end{array}$ \\
\hline IL-6 (mouse) & $\begin{array}{l}\text { F: AGTTGCCTTCTTGGGACTGA } \\
\text { R: TCCACGATTTCCCAGAGAAC }\end{array}$ \\
\hline Cox-2 (mouse) & $\begin{array}{l}\text { F: ATCCTGAGTGGGGTGATGAG } \\
\text { R: GGCAATGCGGTTCTGATACT }\end{array}$ \\
\hline VCAM-1 (mouse) & $\begin{array}{l}\text { F: TCATCCCCACCATTGAAGAT } \\
\text { R: TGAGCAGGTCAGGTTCACAG }\end{array}$ \\
\hline ICAM-1 (mouse) & $\begin{array}{l}\text { F: CCTGTTTCCTGCCTCTGAAG } \\
\text { R: TTAAGGTCCTCTGCGTCTCC }\end{array}$ \\
\hline GAPDH (mouse) & $\begin{array}{l}\text { F: GCATGGCCTTCCGTGTTCCT } \\
\text { R: CCCTGTTGCTGTAGCCGTATTCAT }\end{array}$ \\
\hline
\end{tabular}

$F$, forward; $R$, reverse

and b). To investigate the effect of the class I-selective inhibitor on hypertension, we tested PCI34051 in an Ang II-induced hypertensive mouse model. Systolic blood pressure significantly increased from $101.8 \mathrm{mmHg}$ to 158.8 mmHg following two weeks of Ang II infusion. PCI34051 administration attenuated the increase in systolic blood pressure induced by Ang II (Fig. 1c). To address the

Table 2 IC50 [ $\mu \mathrm{M}]$ values for PCI34051

\begin{tabular}{lcccc}
\hline Compound & HDAC1 & HDAC2 & HDAC3 & HDAC8 \\
\hline PCl34051 & 1.22 & $>10$ & $>10$ & 0.02
\end{tabular}

The in vitro inhibitory activity of $\mathrm{PCl} 34051$ against each $\mathrm{HDAC}$ isoform was determined using the HDAC Fluorogenic Assay Kit from BPS Bioscience. The IC50 values were determined using $0.0001,0.0003,0.01,0.03,0.1,0.3,1$, and $3 \mu \mathrm{M}$ of the inhibitor. 

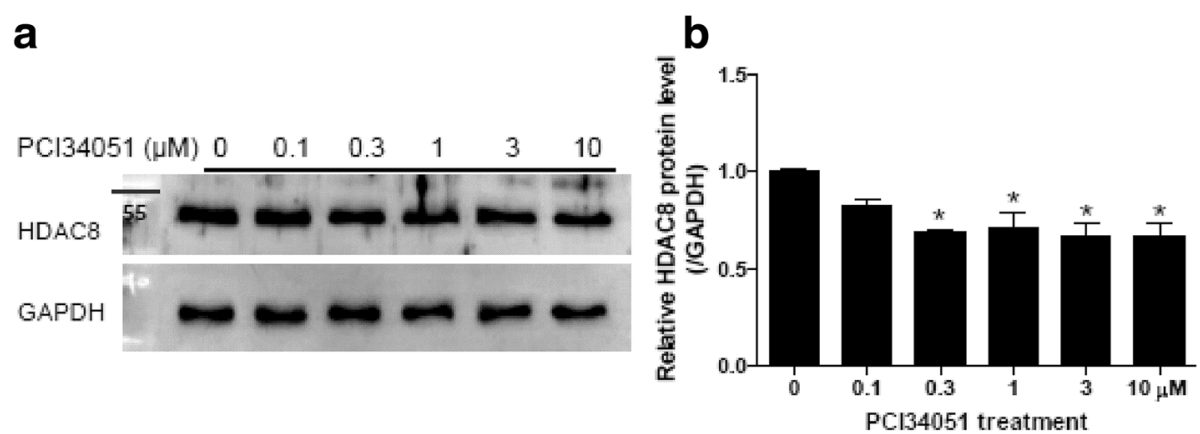

C

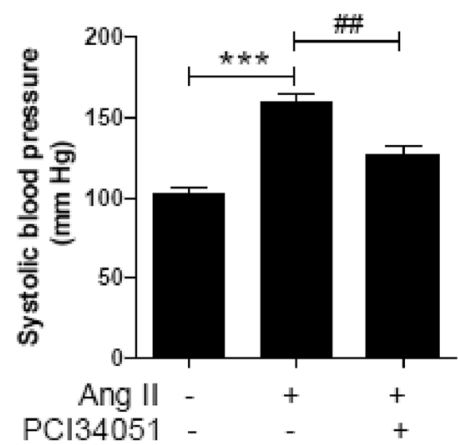

d

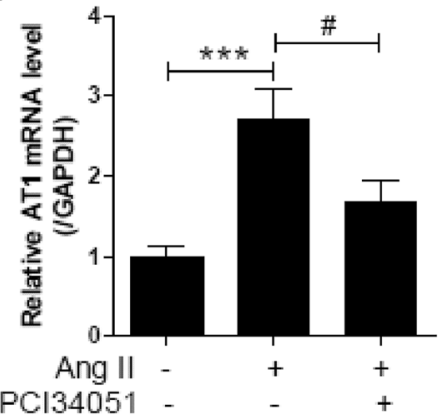

e

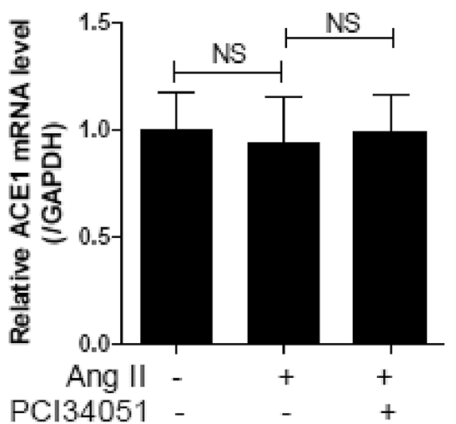

Fig. 1 PCl34051 decreases blood pressure and AT1 mRNA expression in Ang II-infused mice. a Representative western blot images of HDAC8. VSMCs were treated with vehicle or PCl34051 at different concentrations for 24 h. b HDAC 8 protein was quantified using densitometry. ${ }^{*} P<0.05$ versus vehicle-treated VSMCS. c Systolic blood pressures in the experimental groups at 14 th day after Ang II infusion. ${ }^{* *} P<0.001$ versus sham group; \#\# $P<0.01$ versus Ang II-infused group. $\mathbf{d}$ and e Aortic AT1 (d) and ACE1 (e) mRNA expression levels were normalized to GAPDH and relative amounts were calculated. Data are presented as mean \pm SEM ( $n=8$ per group). *** $P<0.001$ versus sham-treated group; \# $P<0.05$ versus Ang II-infused group; NS indicates not significant

potential antihypertensive mechanism of PCI34051, we studied the expression of AT1 and ACE1. As shown in Fig. 1d, AT1 mRNA levels were significantly higher in Ang II-infused mice than in sham-treated mice, and the increase was lower after PCI34051 treatment. However, no significant changes in ACE1 mRNA levels were found across the three groups (Fig. 1e).

\section{PCI34051 reduces aortic wall thickness in Ang II-induced hypertensive mice}

It has been reported that Ang II induces the development of vascular hypertrophy as well as hypertension
[27]. To identify whether PCI34051 regulates vascular hypertrophy, we measured aortic wall thickness after H\&E staining. As shown in Fig. 2a, aortic wall thickness increased approximately 2 -fold in Ang II-infused mice $(87.2 \mu \mathrm{m})$ compared to that in the sham-treated group $(45.4 \mu \mathrm{m})$. PCI34051 significantly decreased the enlarged aortic wall thickness in Ang II-infused mice (Fig. 2b). To explain the reduction of blood vessel thickness by PCI34051, RT-PCR was used to examine the changes in expression of genes related to cell proliferation. E2F3 and GATA6 mRNA expression levels significantly increased in the aortas of Ang II-infused mice compared 

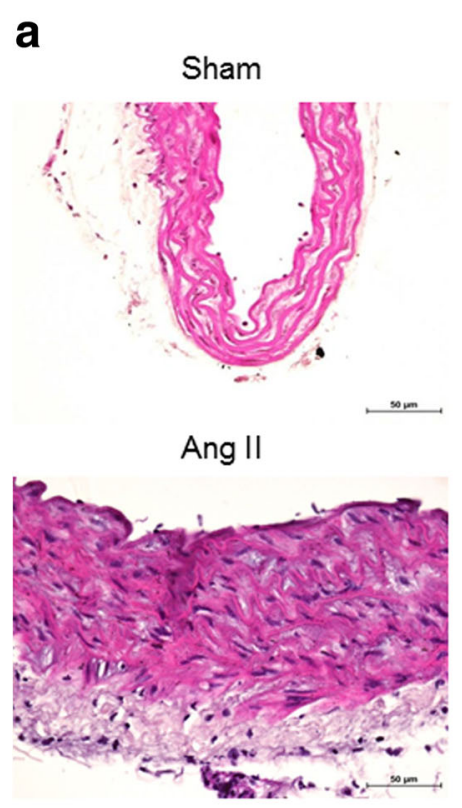

Ang II+PCl34051

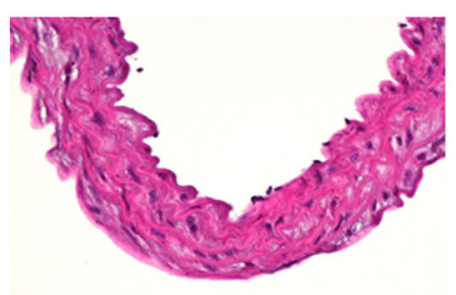

b

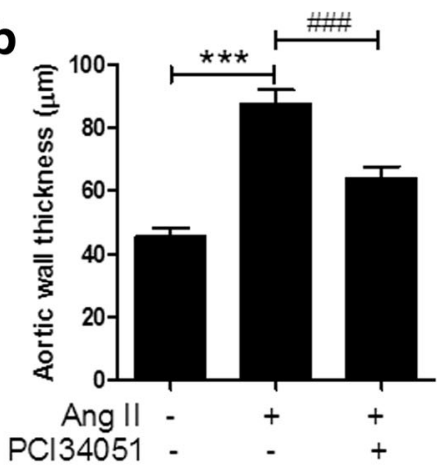

C

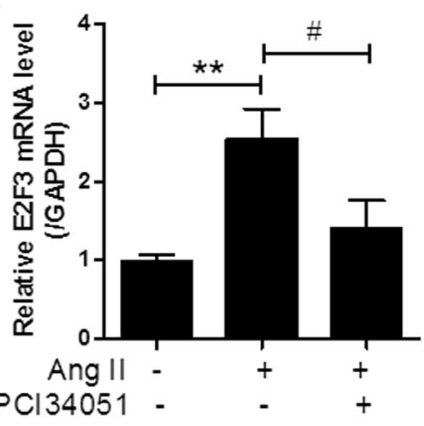

d

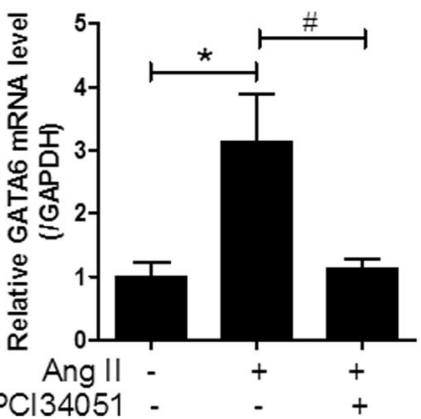

Fig. 2 PCl34051 decreases vascular hypertrophy and expression of cell growth-related genes in Ang II-infused mice. a Representative images of H\&E-stained aorta sections. Scale bar $=50 \mu \mathrm{m}$. b Aortic wall thickness was measured using NIS Elements Software $(\mathrm{n}=8$ per group). ${ }^{* *} P<0.001$ versus sham group; \#\#\# $P<0.001$ versus Ang Il-infused group. E2F3 (c) and GATA6 (d) mRNA expression levels were normalized to GAPDH and relative amounts were calculated. Data are presented as mean \pm SEM $\left(n=8\right.$ per group). ${ }^{*} P<0.05$ and ** $P<0.01$ versus sham-treated group; \# $P<0.05$ versus Ang II-infused group

to those of the sham-treated mice. These increases were attenuated by administration of PCI34051 (Fig. 2c and d).

\section{PCI34051 increases vascular relaxation in rat aortic rings and NO production in HUVECs}

A rat aortic ring test was performed to investigate whether the decrease in blood pressure after PCI34051 administration is associated with vascular tone. PCI34051 treatment induced vascular relaxation both in endothelium-intact and in endothelium-denuded aorta (Fig. 3a), although the effect was higher in endothelium-intact aorta.
We investigated whether vascular relaxation was related to the NO signaling system. We confirmed that pretreatment of the aortic rings with L-NAME (100 $\mu \mathrm{M})$, a NOS inhibitor, prevented blood vessel relaxation by PCI34051 (Fig. 3b). Endothelial NO synthase (eNOS) synthesizes NO in vascular endothelium [28]. To explore whether blood vessel relaxation by PCI34051 is related to NO generation, we studied the effect of PCI34051 on $\mathrm{NO}$ production in HUVECs using a NO-sensitive fluorescent dye, DAF-FM. As shown by the increase in green fluorescence in Fig. 3c, PCI34051 treatment induced NO 

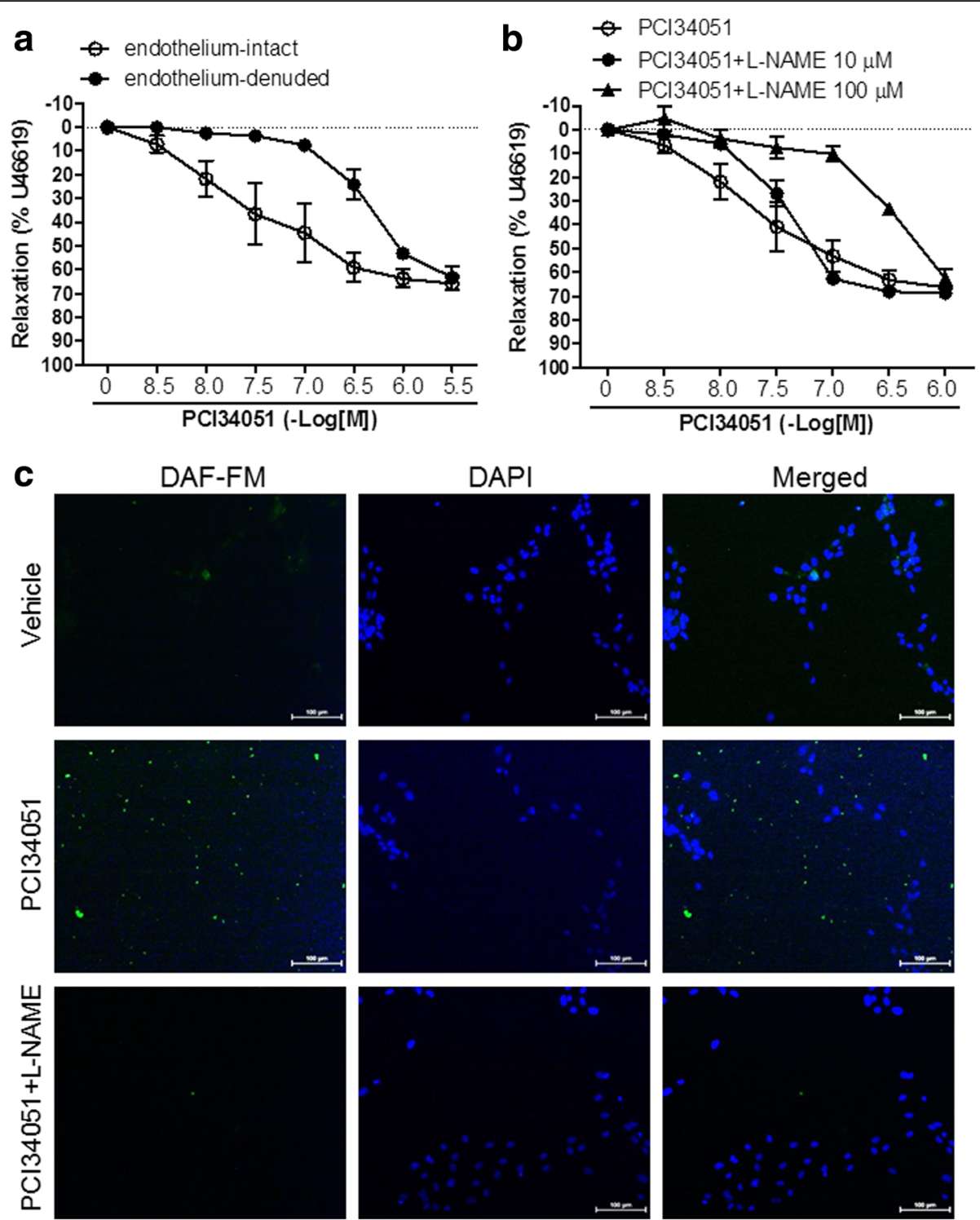

Fig. 3 PCl34051 increases vascular relaxation in rat aortic rings and NO production in HUVECs. a Relaxation of aortic rings in response to PCI34051 was assessed in endothelium-intact and endothelium-denuded aortas. Relaxation is expressed as the percentage of the maximal contractile response to U46619. Data are presented as mean \pm SEM ( $n=4$ per group). $\mathbf{b}$ Endothelium-intact rat aortic rings were pretreated with $N^{G}$-nitro-L-arginine methyl ester (L- NAME, $10 \mu \mathrm{M}$ or $100 \mu \mathrm{M}$ ) or vehicle for $30 \mathrm{~min}$. When vascular contractions induced by U46619 (30 nM) reached a plateau, PCI34051 was added cumulatively to elicit relaxation. Data are presented as mean \pm SEM ( $n=4$ per group). $\mathbf{c ~ H U V E C s ~ w e r e ~ t r e a t e d ~ w i t h ~ P C I 3 4 0 5 1 ~ ( 1 ~} \mu \mathrm{M})$ in the presence or absence of L-NAME $(250 \mu \mathrm{M})$ for $24 \mathrm{~h}$ and then labeled with a fluorescent NO indicator, DAF-FM DA $(2.5 \mu \mathrm{M})$, for $30 \mathrm{~min}$. Three independent experiments were conducted and representative images are shown. Scale bar $=100 \mu \mathrm{m}$

synthesis. Pretreatment with L-NAME reduced the amount of NO generated by PCI34051 in HUVECs.

\section{PCI34051 attenuates inflammation in Ang II-induced hypertensive mice}

Many studies have reported that inflammatory responses participate in the pathophysiology of hypertension $[5,29$, 30]. Tumor necrosis factor- $\alpha$ (TNF- $\alpha$ ) regulates blood pressure in the kidneys during inflammatory conditions such as salt-sensitive hypertension [31, 32]. Interleukin-1 beta (IL-1 $\beta$ ) levels are elevated in hypertension [33]. Monocyte chemoattractant protein-1 (MCP-1) is increased in Ang II-induced hypertension [34]. TNF- $\alpha$, IL-1 $\beta$, and MCP-1 are proinflammatory cytokines or chemokines. PCI34051 treatment significantly suppressed Ang II-induced TNF- $\alpha$, IL-1 $\beta$, and MCP-1 mRNA expression in the aorta (Fig. $4 \mathrm{a}-\mathrm{c}$ ). High NO levels are detrimental to the cardiovascular system and are associated with inducible NOS (iNOS) expression [35]. IL-6 expression is higher in hypertensive animal models and hypertensive 

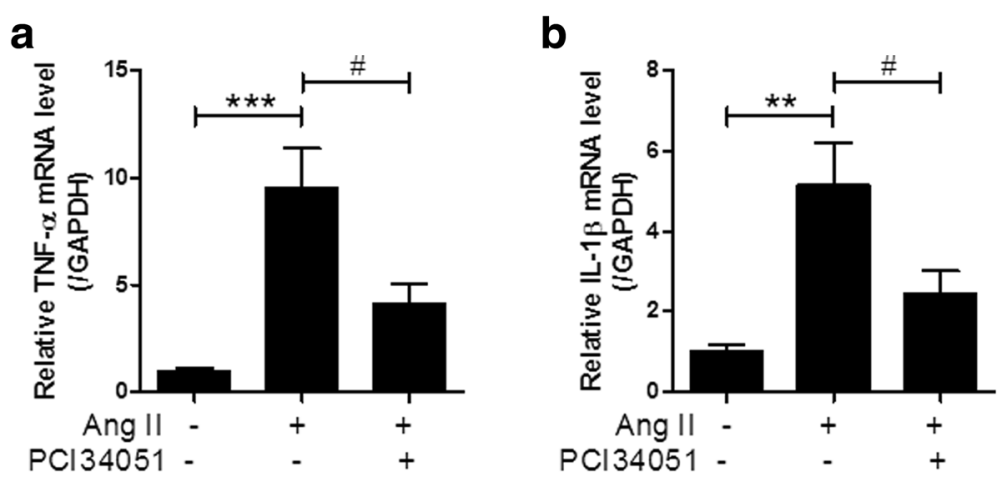

C

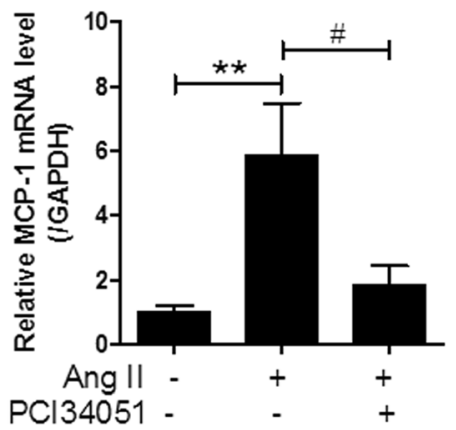

d
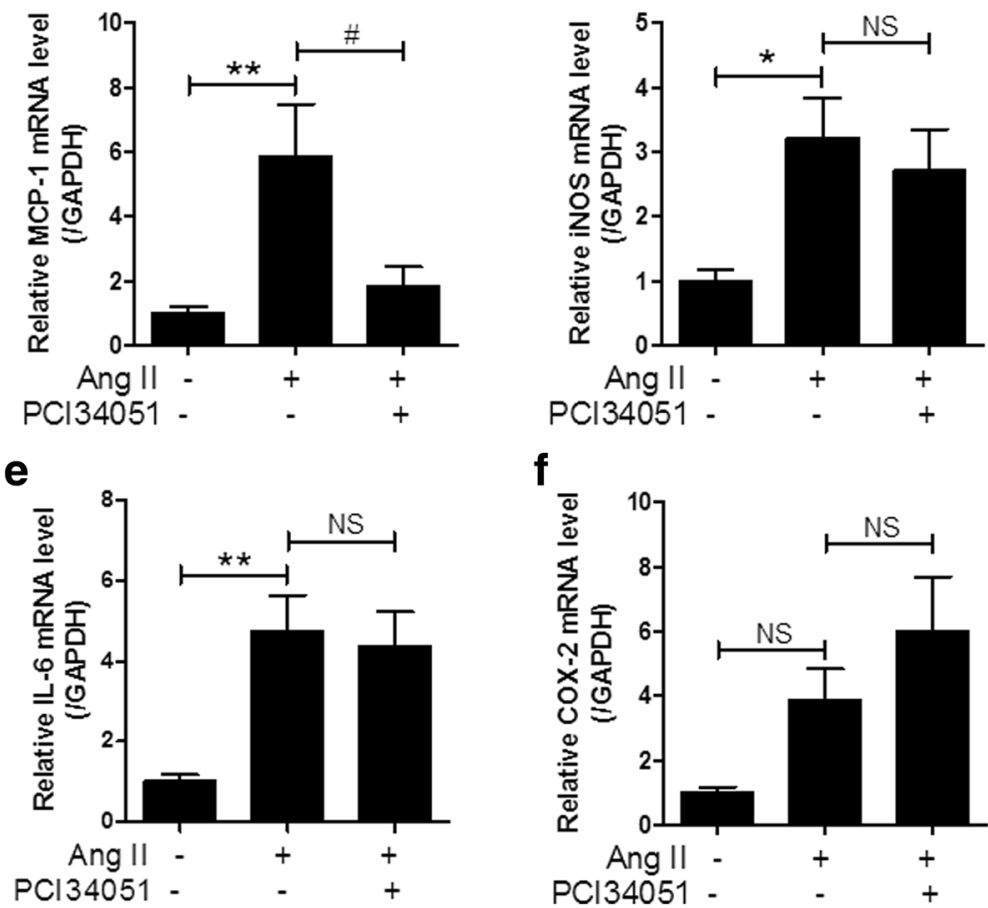

f

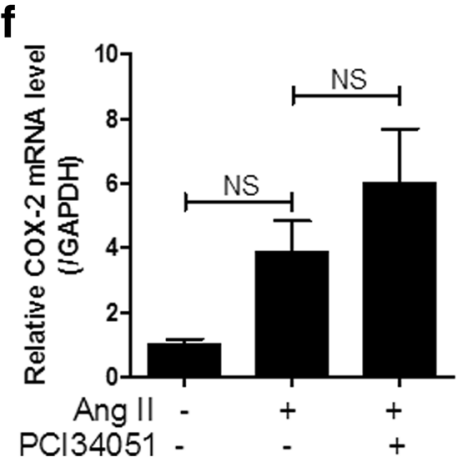

Fig. 4 PCI34051 suppresses proinflammatory cytokines in aortic tissues of Ang II- infused mice TNF-a (a), IL-1 $\beta$ (b), MCP-1 (c), iNOS (d), IL-6 (e), and Cox-2 (f) mRNA expression in the aorta were normalized to GAPDH, and the relative expression was quantified. Data are presented as mean \pm SEM ( $n=8$ per group). ${ }^{*} P<0.05,{ }^{* *} P<0.01$, and ${ }^{* * *} P<0.001$ versus sham-treated group; $\# P<0.05$ versus Ang II-infused group; NS indicates not significant

humans than in normotensives [36]. The expression of iNOS and IL-6 mRNA significantly increased in the aorta tissues of Ang II-infused mice but was not affected by PCI34051 treatment (Fig. 4d and e). Cyclooxygenase-2 (COX-2) is enhanced in vascular smooth muscle cells in response to an Ang II stimulus [37]. However, there was no significant difference in the expression of COX-2 between groups (Fig. 4f).

\section{PCI34051 reduces adhesion molecules in Ang Il-induced} hypertensive mice

Adhesion molecules mediate the interactions between blood cells and endothelial cells under pathological conditions [38]. Adhesion molecules, including ICAM-1, VCAM-1, and E- selectin, are located on the surface of endothelial cells and are highly increased in the blood in response to pathological conditions [39, 40]. Hypertensive patients have been reported to have higher circulating levels of soluble ICAM-1 (sICAM-1) and VCAM-1 (sVCAM-1) than normotensive people [11]. The mRNA levels of VCAM-1 and ICAM-1 were higher in the aortas of the Ang II-infused mice than in those of the control group and were significantly decreased by PCI34051 treatment (Fig. 5a and b). Immunohistochemistry revealed that VCAM-1 was highly expressed in the endothelium of Ang II-treated aortas compared to those 

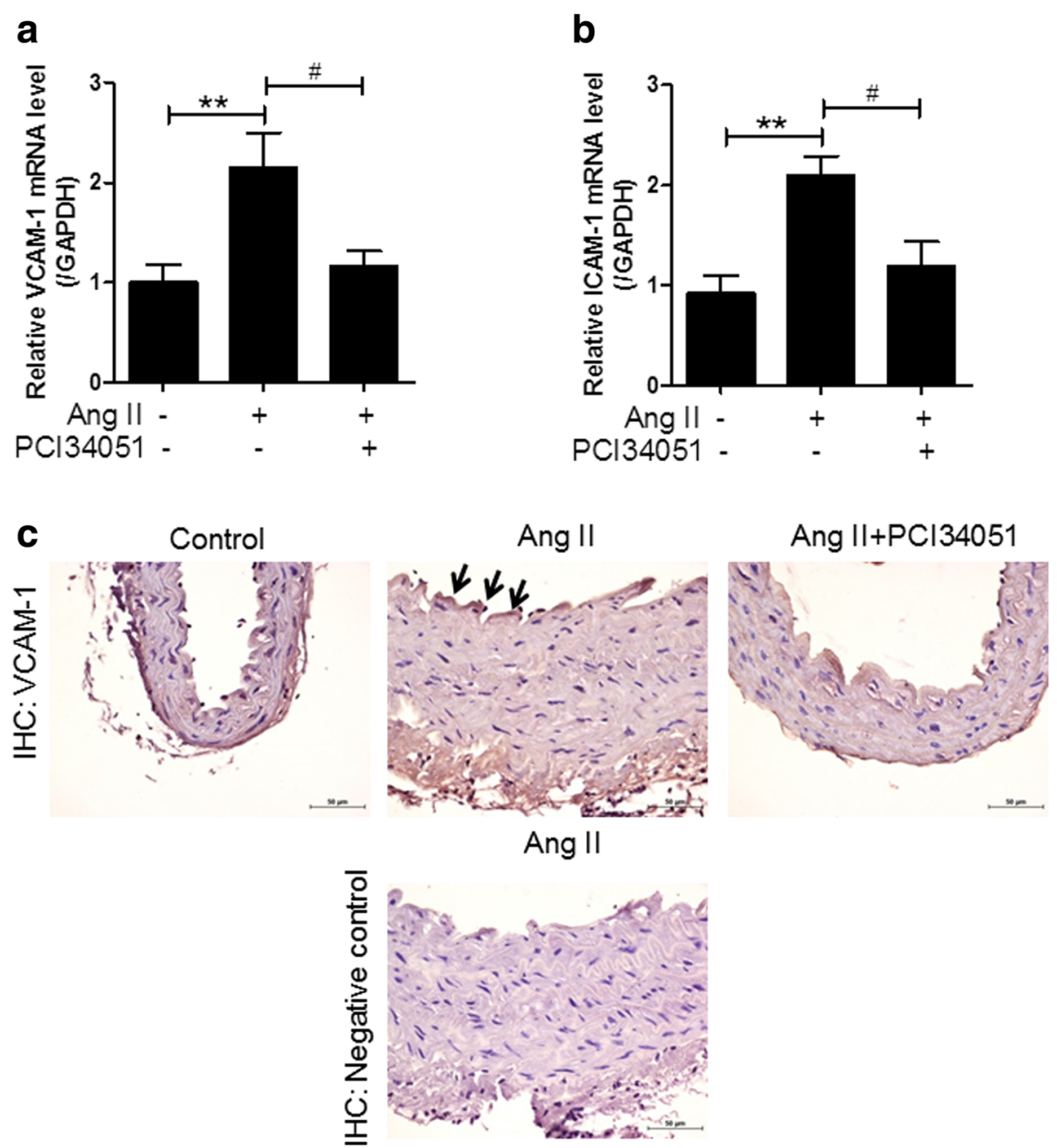

Fig. 5 PCI34051 inhibits the expression of adhesion molecules in aortic tissues of Ang II-infused mice VCAM-1 (a) and ICAM-1 (b) aortic mRNA expression levels were normalized to GAPDH and relative amounts were calculated. Data are presented as mean \pm SEM $\left(n=8\right.$ per group). ${ }^{* *} P<0.01$ versus sham-treated group; \# $P<0.05$ versus Ang II-infused group. c VCAM-1 expression was assessed by immunohistochemistry. Arrows indicate the expression of VCAM-1 in the aorta (brown). Scale bar $=50 \mu \mathrm{m}$. The lower Ang II-infused group image shows a negative control.

of the controls (Fig. 5c). After treatment with PCI34051, VCAM-1 expression was attenuated.

\section{PCI34051 does not affect NADPH oxidase (Nox) in Ang II-} induced hypertensive mice

Ang II is associated with oxidative stress in hypertension. Nicotinamide adenine dinucleotide phosphate (NADPH) oxidases (Nox) generate reactive oxygen species (ROS), leading to vascular damage [41]. The expression of Nox1 and Nox 2 mRNA were significantly increased in the Ang II-infused group compared to the sham-treated group, but this was not attenuated by PCI34051 administration (Fig. 6a and b). The p22phox is an essential component of the membrane-associated enzyme phagocyte Nox and the p47phox is a regulatory subunit of Nox. However, Nox4 and p22phox mRNA expression was not increased in the Ang II-infused group (Fig. 6c and d). Although not significant, p47phox mRNA showed an increasing trend after Ang II administration, but this was not affected by PCI34051 administration (Fig. 6e).

\section{Discussion}

In the present study, we demonstrated that PCI34051, an HDAC8-selective inhibitor, lowered systolic blood pressure, reduced aortic wall thickness, increased vascular relaxation, and inhibited inflammation in a mouse model of Ang II-induced hypertension.

Although there are reports that HDAC inhibitors lower blood pressure [21] in various diseases including essential hypertension, high-fat diet-induced hypertension [42], and Cushing's syndrome [43], in many circumstances we do not know which isoform of HDAC is involved. Initially, in a cell-free system, we observed that 

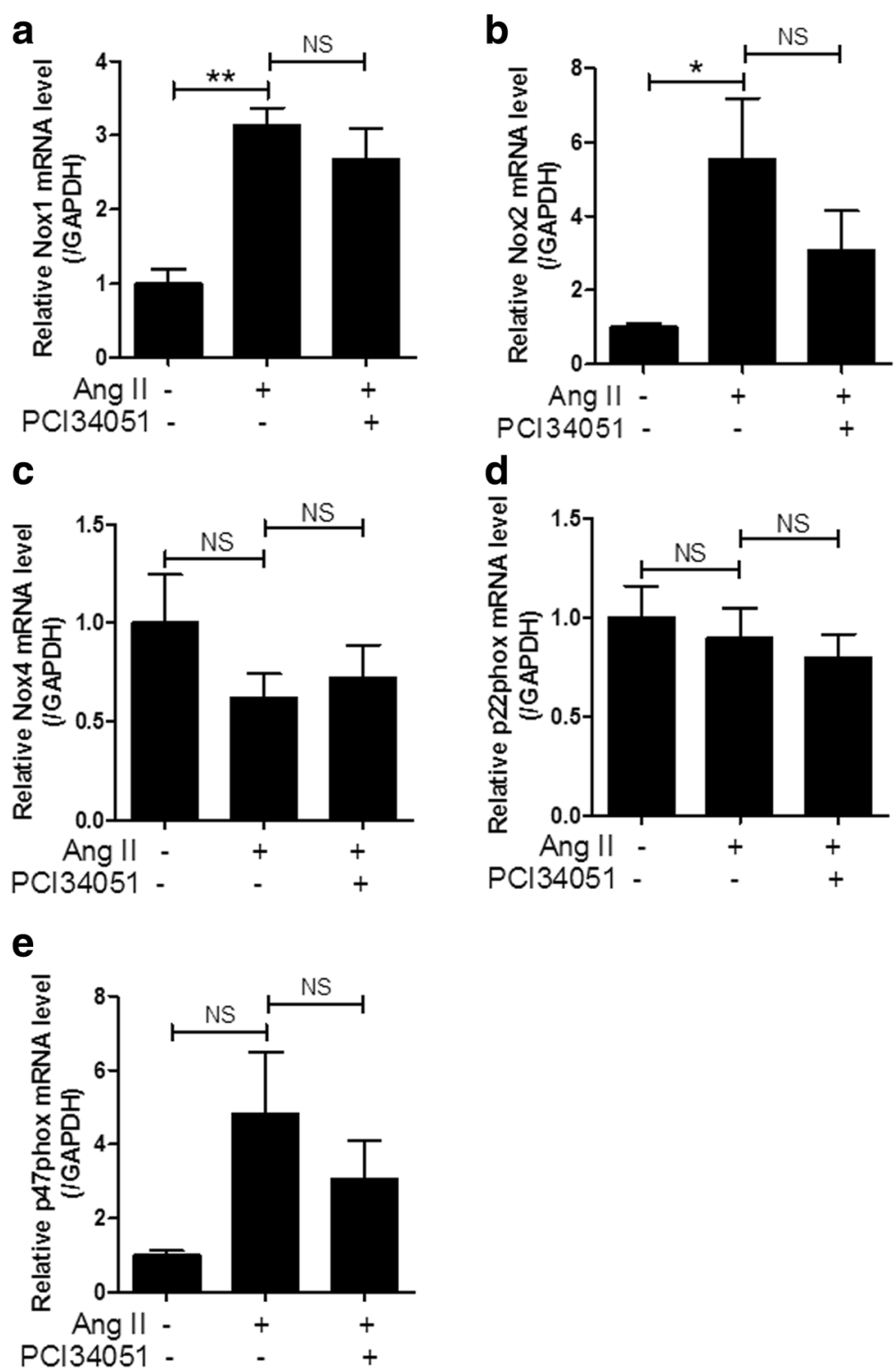

Fig. 6 PCl34051 does not affect Nox isoforms or Nox subunits in Ang II-infused mice. Aortic mRNA expression levels of Nox1 (a), Nox2 (b), and Nox4 (c), and Nox subunits p22phox (d) and p47phox (e), were normalized to GAPDH and relative amounts were calculated. Data are presented as mean \pm SEM ( $n=8$ per group). ${ }^{*} P<0.05$ and ${ }^{* *} P<0.01$ versus sham-treated group; NS indicates not significant

PCI34051 selectively inhibits HDAC8 enzyme activity, but not the activities of HDAC1, HDAC2, or HDAC3.

Ang II causes hypertension through effects on the AT1 receptor, leading to vascular contraction [44]. It is well known that ARBs act by selectively blocking the binding of Ang II to the AT1 receptor [45]. In the present study, we observed that PCI34051 administration significantly decreased systolic blood pressure in Ang II-infused mice by decreasing AT1 mRNA expression. However, blood pressure was not fully returned to control levels by PCI34051 administration, implying that other HDACs may be involved, in addition to HDAC8.
There have been reports that drugs such as calcium-calmodulin-dependent kinase II inhibitor (KN-93) and HDAC inhibitor (MC1568) are effective in reducing Ang II-induced vascular hypertrophy $[24,46]$. In the present study, the HDAC8-selective inhibitor, PCI34051, was also effective in partially reducing the vascular hypertrophy induced by Ang II. In our previous research [24], GATA6 transcription factor directly increased the size of vascular smooth muscle cells. E2F3 is well known as a transcription factor that regulates cell proliferation [47]. Our results show that the inhibitory effect of PCI34051 on vascular hypertrophy may be due to its inhibition of 
GATA6 and E2F3 expression, as a decrease in the mRNA expression of these transcription factors was seen in the Ang II-infused mice after PCI34051 administration.

The most interesting finding is that PCI34051 relaxes blood vessels in rat aortic rings. The blood vessel relaxation by PCI34051 is particularly dependent on endothelial cells and is effected through the NO signaling system. Indeed, we demonstrated that PCI34051 treatment induced NO production in HUVECs and that this could be blocked by a NOS inhibitor.

This result suggests that HDAC8 activity is closely related to vascular contraction and relaxation. In contrast to our results, Lee et al reported that a pan-HDAC inhibitor, CG200745, had little effect on vascular relaxation in DOCA-induced hypertension [48]. However, in agreement with our results, SAHA, a pan-HDAC inhibitor, or trichostatin A (TSA) caused a dose-dependent relaxation of the phenylephrine-induced vascular contraction of mouse aortas or the Ang II-induced contraction of rat aortas $[49,50]$. Long-term treatment with TSA inhibited Ang II-induced contraction in spontaneously hypotensive rats [51]. Some researchers have used pan-HDAC inhibitors, so we cannot be sure which HDACs have an effect on vascular relaxation.

Ang II induces vascular inflammation by inducing proinflammatory cytokines [52]. The HDAC8-selective inhibitor decreased the expression of the proinflammatory cytokines, TNF $\alpha$, IL-1 $\beta$, and MCP-1, and suppressed inflammation, suggesting that these two effects may be linked. Adhesion molecules are also implicated in inflammation. ICAM-1 and VCAM-1 mediate adhesion of leukocytes to the endothelium. sICAM-1, sVCAM-1, P-selectin, and E- selectin levels have been seen to be higher in hypertensive patients [53]. In addition, the expression of VCAM-1 was increased in the aortas and mesenteric resistance arteries of Ang II-induced hypertensive mice [54]. Our current study shows that treatment with an HDAC8- 18 selective inhibitor suppresses the increased expression of VCAM-1 and ICAM-1 in Ang II- induced hypertension. Furthermore, immunohistochemistry demonstrated that VCAM-1 protein was highly expressed in the endothelium of aorta tissues in Ang II-infused mice compared to that in control mice. Our findings suggest that HDAC8 activity may well be responsible for vascular inflammation.

Ang II regulates ROS through upregulation of Nox [41]. Angiotensin II-induced ROS can cause vasoconstriction, inflammation, and vascular remodeling through activation of multiple pathways. In our study, Ang II increased the aortic expression of Nox1 and Nox 2 mRNA but did not affect the expression of Nox4. The HDAC8-selective inhibitor did not decrease Nox1 and Nox2 expression. This result implies that HDACs other than HDAC8 modulate Nox expression. Cardiac Nox1, Nox2, and Nox4 mRNA levels significantly increased in SHR hypertensive rats compared to that in Wistar Kyoto (WKY) control rats [55]. Gallic acid, which inhibits HDAC5, HDAC7, HDAC8, and HDAC9, ameliorated Nox2 mRNA and protein levels in SHR [56]. Manea et al. reported that SAHA decreased the aortic expression of Nox1, Nox2, and Nox4 in diabetic mice by regulation of HDAC1 and HDAC2 [57]. In contrast, increased expression of HDAC3, HDAC4, and HDAC5 is associated with induction of Nox2 and Nox4 in pulmonary arterial hypertension, which was decreased by the HDAC inhibitor, valproic acid [58]. The results of the above study show that the expression of Nox varies depending on the type of disease; for example, arterial hypertension, pulmonary hypertension, or diabetes. The pan-HDAC inhibitor was more effective in reducing the expression of Nox than an HDAC isoform-specific inhibitor.

\section{Conclusions}

We demonstrated that an HDAC8-selective inhibitor lowered blood pressure, inhibited vascular hypertrophy and inflammation, and relaxed blood vessels in an Ang II-induced hypertension model. The HDAC8-selective inhibitor contributed to blood pressure reduction by inhibiting a component of the RAS or regulating NO signaling pathways. We suggest that HDAC8 may be a therapeutic target for hypertension.

\begin{abstract}
Abbreviations
Ang II: Angiotensin II; ARB: Angiotensin II receptor blocker; AT1: Angiotensin II receptor type I; COX-2: Cyclooxygenase-2; DAF-FM DA: 4-amino-5-

methylamino-2, $7^{\prime}$-difluorofluorescein diacetate; DOCA: Deoxycorticosterone acetate; EBM: Endothelial cell basal medium; H\&E: Hematoxylin and eosin; HDACs: Histone deacetylases; HUVECs: Human umbilical vascular endothelial cells; IC50: Half-maximal inhibitory concentration; ICAM-1: Intercellular adhesion molecule-1; IL-1ß: Interleukin-1 beta iNOS: inducible nitric oxide synthase; L-NAME: NG-nitro-L-arginine methyl ester; MCP-1: Monocyte chemoattractant protein-1; NADPH: Nicotinamide adenine dinucleotide phosphate; NO: Nitric oxide; Nox: NADPH oxidase; PECAM: Platelet endothelial cell adhesion molecule; SVCAM-1: soluble VCAM-1; TNF-a: Tumor necrosis factor-a; VCAM-1: Vascular cell adhesion molecule-1
\end{abstract}

\section{Acknowledgements}

Not applicable.

Funding

This study is supported by the Korean Society of Hypertension (2017).

\section{Availability of data and materials}

The raw data supporting the findings presented in this study will be available from the corresponding author upon request.

\section{Authors' contributions}

HJK designed the research; YR, YMS, SS, GRK, SYC, performed the experiments; HJK, YR, YMS, MHJ performed data analysis and interpreted the data; HJK wrote the paper. All authors read and approved the final manuscript.

\section{Ethics approval and consent to participate}

All animal experiments were approved by the Animal Experiment Committee of the Chonnam National University Medical School (CNU IACUC-H-2017-70) and carried out in accordance with the Guide for the 
Care and Use of Laboratory Animals (US National Institutes of Health Publication, 8th edition, 2011).

\section{Consent for publication}

Not applicable.

\section{Competing interests}

The authors declare that they have no competing interest.

\section{Publisher's Note}

Springer Nature remains neutral with regard to jurisdictional claims in published maps and institutional affiliations.

\section{Author details}

${ }^{1}$ Heart Research Center of Chonnam National, Jebong-ro, Dong-gu, Gwangju 61469, Republic of Korea. ${ }^{2}$ Hypertension Heart Failure Research Center, Chonnam National University Hospital, Gwangju 61469, Republic of Korea. ${ }^{3}$ National Development Institute of Korean Medicine, Hwarang-ro, Gyeongsan-si, Gyeongsangbuk-do, Republic of Korea. ${ }^{4}$ Molecular Medicine, Brain Korea 21 PLUS, Chonnam National University Graduate School, Gwangju 61469, Republic of Korea.

\section{Received: 30 October 2018 Accepted: 18 February 2019} Published online: 15 June 2019

\section{References}

1. Suri MF, Qureshi Al. Hypertensive retinopathy and risk of cardiovascular diseases in a national cohort. J Vasc Interv Neurol. 2008;1:75-8.

2. Wong TY, Mclntosh R. Hypertensive retinopathy signs as risk indicators of cardiovascular morbidity and mortality. Br Med Bull. 2005;73-74:57-70.

3. Bakris G, Sarafidis P, Agarwal R, Ruilope L. Review of blood pressure control rates and outcomes. J Am Soc Hypertens. 2014;8:127-41.

4. Boos CJ, Lip GY. Is hypertension an inflammatory process? Curr Pharm Des. 2006;12:1623-35.

5. Savoia C, Schiffrin EL. Inflammation in hypertension. Curr Opin Nephrol Hypertens. 2006;15:152-8.

6. Cheng ZJ, Vapaatalo H, Mervaala E. Angiotensin II and vascular inflammation. Med Sci Monit. 2005;11:RA194-205.

7. Pueyo ME, Gonzalez W, Nicoletti A, Savoie F, Arnal JF, Michel JB. Angiotensin II stimulates endothelial vascular cell adhesion molecule-1 via nuclear factor-kappaB activation induced by intracellular oxidative stress. Arterioscler Thromb Vasc Biol. 2000;20:645-51.

8. Pastore L, Tessitore A, Martinotti S, Toniato E, Alesse E, Bravi MC, et al. Angiotensin II stimulates intercellular adhesion molecule-1 (ICAM-1) expression by human vascular endothelial cells and increases soluble ICAM1 release in vivo. Circulation. 1999:100:1646-52.

9. Shalia KK, Mashru MR, Vasvani JB, Mokal RA, Mithbawkar SM, Thakur PK. Circulating levels of cell adhesion molecules in hypertension. Indian J Clin Biochem. 2009;24:388-97.

10. Miller MA, Kerry SM, Cook DG, Cappuccio FP. Cellular adhesion molecules and blood pressure: interaction with sex in a multi-ethnic population. J Hypertens. 2004;22:705-11.

11. DeSouza CA, Dengel DR, Macko RF, Cox K, Seals DR. Elevated levels of circulating cell adhesion molecules in uncomplicated essential hypertension. Am J Hypertens. 1997;10:1335-41.

12. Mu W, Chen M, Gong Z, Zheng F, Xing Q. Expression of vascular cell adhesion molecule- 1 in the aortic tissues of atherosclerotic patients and the associated clinical implications. Exp Ther Med. 2015;10:423-8.

13. Kuroda YT, Komamura K, Tatsumi R, Mori K, Yoneda K, Katayama Y, et al. Vascular cell adhesion molecule-1 as a biochemical marker of left ventricular mass in the patients with hypertension. Am J Hypertens. 2001;14:868-72.

14. Dandona P, Dhindsa S, Ghanim H, Chaudhuri A. Angiotensin II and inflammation: the effect of angiotensin-converting enzyme inhibition and angiotensin II receptor blockade. J Hum Hypertens. 2007;21:20-7.

15. Goulopoulou S, Webb RC. Symphony of vascular contraction: how smooth muscle cells lose harmony to signal increased vascular resistance in hypertension. Hypertension. 2014;63:e33-9.

16. Rembold CM. Regulation of contraction and relaxation in arterial smooth muscle. Hypertension. 1992;20:129-37.

17. Yoon S, Eom GH. HDAC and HDAC inhibitor: from Cancer to cardiovascular diseases. Chonnam Med J. 2016;52(1):11.
18. McKinsey TA. Therapeutic potential for HDAC inhibitors in the heart. Annu Rev Pharmacol Toxicol. 2012;52:303-19.

19. Kee HJ, Sohn IS, Nam KI, Park JE, Qian YR, Yin Z, et al. Inhibition of histone deacetylation blocks cardiac hypertrophy induced by angiotensin II infusion and aortic banding. Circulation. 2006;113:51-9.

20. Cao DJ, Wang ZV, Battiprolu PK, Jiang N, Morales CR, Kong Y, et al. Histone deacetylase (HDAC) inhibitors attenuate cardiac hypertrophy by suppressing autophagy. Proc Natl Acad Sci U S A. 2011;108:4123-8.

21. Cardinale JP, Sriramula S, Pariaut R, Guggilam A, Mariappan N, Elks CM, et al. HDAC inhibition attenuates inflammatory, hypertrophic, and hypertensive responses in spontaneously hypertensive rats. Hypertension. 2010;56:437-44.

22. Lee HA, Lee DY, Cho HM, Kim SY, Iwasaki Y, Kim IK. Histone deacetylase inhibition attenuates transcriptional activity of mineralocorticoid receptor through its acetylation and prevents development of hypertension. Circ Res. 2013;112:1004-12

23. Kee HJ, Bae EH, Park S, Lee KE, Suh SH, Kim SW, et al. HDAC inhibition suppresses cardiac hypertrophy and fibrosis in DOCA-salt hypertensive rats via regulation of HDAC6/HDAC8 enzyme activity. Kidney Blood Press Res. 2013;37:229-39

24. Kim GR, Cho SN, Kim HS, Yu SY, Choi SY, Ryu Y, et al. Histone deacetylase and GATA-binding factor 6 regulate arterial remodeling in angiotensin IIinduced hypertension. J Hypertens. 2016;34:2206-19.

25. Ingham OJ, Paranal RM, Smith WB, Escobar RA, Yueh H, Snyder T, et al. Development of a potent and selective HDAC8 inhibitor. ACS Med Chem Lett. 2016;7:929-32.

26. Balasubramanian S, Ramos J, Luo W, Sirisawad M, Verner E, Buggy JJ. A novel histone deacetylase 8 (HDAC8)-specific inhibitor PCl-34051 induces apoptosis in T-cell lymphomas. Leukemia. 2008;22:1026-34.

27. Zhang Y, Griendling KK, Dikalova A, Owens GK, Taylor WR. Vascular hypertrophy in angiotensin II-induced hypertension is mediated by vascular smooth muscle cell-derived H2O2. Hypertension. 2005:46:732-7.

28. Fish JE, Marsden PA. Endothelial nitric oxide synthase: insight into cellspecific gene regulation in the vascular endothelium. Cell Mol Life Sci. 2006; 63:144-62.

29. Harrison DG, Guzik TJ, Lob HE, Madhur MS, Marvar PJ, Thabet SR, et al. Inflammation, immunity, and hypertension. Hypertension. 2011;57:132-40.

30. Dinh QN, Drummond GR, Sobey CG, Chrissobolis S. Roles of inflammation, oxidative stress, and vascular dysfunction in hypertension. Biomed Res Int. 2014:2014:406960

31. Mehaffey E, Majid DSA. Tumor necrosis factor-alpha, kidney function, and hypertension. Am J Physiol Renal Physiol. 2017;313:F1005-F8.

32. Ramseyer VD, Garvin JL. Tumor necrosis factor-alpha: regulation of renal function and blood pressure. Am J Physiol Renal Physiol. 2013;304:F1231-42.

33. Krishnan SM, Sobey CG, Latz E, Mansell A, Drummond GR. IL-1 beta and IL18: inflammatory markers or mediators of hypertension? Br J Pharmacol. 2014;171:5589-602.

34. Chen XL, Tummala PE, Olbrych MT, Alexander RW, Medford RM. Angiotensin II induces monocyte chemoattractant protein-1 gene expression in rat vascular smooth muscle cells. Circ Res. 1998;83:952-9.

35. Oliveira-Paula GH, Lacchini R, Tanus-Santos JE. Inducible nitric oxide synthase as a possible target in hypertension. Curr Drug Targets. 2014;15: 164-74.

36. Chamarthi B, Williams GH, Ricchiuti V, Srikumar N, Hopkins PN, Luther $J M$, et al. Inflammation and hypertension: the interplay of interleukin-6, dietary sodium, and the renin-angiotensin system in humans. Am J Hypertens. 2011;24:1143-8.

37. Hernandez J, Astudillo H, Escalante B. Angiotensin II stimulates cyclooxygenase-2 mRNA expression in renal tissue from rats with kidney failure. Am J Physiol Ren Physiol. 2002;282:F592-8.

38. Krieglstein CF, Granger DN. Adhesion molecules and their role in vascular disease. Am J Hypertens. 2001;14:44S-54S.

39. Videm V, Albrigtsen M. Soluble ICAM-1 and VCAM-1 as markers of endothelial activation. Scand J Immunol. 2008;67:523-31.

40. Cook-Mills JM, Marchese ME, Abdala-Valencia H. Vascular cell adhesion molecule-1 expression and signaling during disease: regulation by reactive oxygen species and antioxidants. Antioxid Redox Signal. 2011; 15:1607-38.

41. Nguyen Dinh Cat A, Montezano AC, Burger D, Touyz RM. Angiotensin II, NADPH oxidase, and redox signaling in the vasculature. Antioxid Redox Signal. 2013;19:1110-20. 
42. Choi J, Park S, Kwon TK, Sohn SI, Park KM, Kim Jl. Role of the histone deacetylase inhibitor valproic acid in high-fat diet-induced hypertension via inhibition of HDAC1/angiotensin II axis. Int J Obes. 2017;41:1702-9.

43. Lee HA, Kang SH, Kim M, Lee E, Cho HM, Moon EK, et al. Histone deacetylase inhibition ameliorates hypertension and hyperglycemia in a model of Cushing's syndrome. Am J Physiol Endocrinol Metab. 2018; 314:E39-52

44. Crowley SD, Gurley SB, Herrera MJ, Ruiz P, Griffiths R, Kumar AP, et al. Angiotensin II causes hypertension and cardiac hypertrophy through its receptors in the kidney. Proc Natl Acad Sci U S A. 2006;103:17985-90.

45. Siragy HM, Bedigian M. Mechanism of action of angiotensin-receptor blocking agents. Curr Hypertens Rep. 1999;1:289-95.

46. Li H, Li W, Gupta AK, Mohler PJ, Anderson ME, Grumbach IM. Calmodulin kinase II is required for angiotensin II-mediated vascular smooth muscle hypertrophy. Am J Physiol Heart Circ Physiol. 2010;298:H688-98.

47. Humbert PO, Verona R, Trimarchi JM, Rogers C, Dandapani S, Lees JA. E2f3 is critical for normal cellular proliferation. Genes Dev. 2000;14:690-703.

48. Lee E, Song MJ, Lee HA, Kang SH, Kim M, Yang EK, et al. Histone deacetylase inhibitor, CG200745, attenuates cardiac hypertrophy and fibrosis in DOCA-induced hypertensive rats. Kor J Physiol Pharmacol. 2016;20:477-85.

49. Zheng C, Zhong M, Qi Z, Shen F, Zhao Q, Wu L, et al. Histone deacetylase inhibitors relax mouse aorta partly through their inhibitory action on L-type ca(2+) channels. J Pharmacol Exp Ther. 2017;363:211-20.

50. Kang G, Lee YR, Joo HK, Park MS, Kim CS, Choi S, et al. Trichostatin a modulates angiotensin II-induced vasoconstriction and blood pressure via inhibition of p66shc activation. Kor J Physiol Pharmacol. 2015;19:467-72.

51. Usui T, Okada M, Mizuno W, Oda M, Ide N, Morita T, et al. HDAC4 mediates development of hypertension via vascular inflammation in spontaneous hypertensive rats. Am J Physiol Heart Circ Physiol. 2012;302:H1894-904.

52. Savoia C, Schiffrin EL. Vascular inflammation in hypertension and diabetes: molecular mechanisms and therapeutic interventions. Clin Sci (Lond). 2007; 112:375-84.

53. Nomura S, Kanazawa S, Fukuhara S. Effects of efonidipine on platelet and monocyte activation markers in hypertensive patients with and without type 2 diabetes mellitus. J Hum Hypertens. 2002;16:539-47.

54. De Ciuceis C, Amiri F, Brassard P, Endemann DH, Touyz RM, Schiffrin EL. Reduced vascular remodeling, endothelial dysfunction, and oxidative stress in resistance arteries of angiotensin II-infused macrophage colonystimulating factor-deficient mice: evidence for a role in inflammation in angiotensin-induced vascular injury. Arterioscler Thromb Vasc Biol. 2005;25 2106-13.

55. Jin L, Piao ZH, Sun S, Liu B, Kim GR, Seok YM, et al. Gallic acid reduces blood pressure and attenuates oxidative stress and cardiac hypertrophy in spontaneously hypertensive rats. Sci Rep. 2017;7:15607.

56. Choi SY, Kee HJ, Jin L, Ryu Y, Sun S, Kim GR, et al. Inhibition of class lla histone deacetylase activity by gallic acid, sulforaphane, TMP269, and panobinostat. Biomed Pharmacother. 2018;101:145-54.

57. Manea SA, Antonescu ML, Fenyo IM, Raicu M, Simionescu M, Manea A. Epigenetic regulation of vascular NADPH oxidase expression and reactive oxygen species production by histone deacetylase- dependent mechanisms in experimental diabetes. Redox Biol. 2018;16:332-43.

58. Chen F, Li X, Aquadro E, Haigh S, Zhou J, Stepp DW, et al. Inhibition of histone deacetylase reduces transcription of NADPH oxidases and ROS production and ameliorates pulmonary arterial hypertension. Free Radic Biol Med. 2016;99:167-78.

\section{Ready to submit your research? Choose BMC and benefit from:}

- fast, convenient online submission

- thorough peer review by experienced researchers in your field

- rapid publication on acceptance

- support for research data, including large and complex data types

- gold Open Access which fosters wider collaboration and increased citations

- maximum visibility for your research: over $100 \mathrm{M}$ website views per year

At BMC, research is always in progress.

Learn more biomedcentral.com/submissions 